PRACE GEOGRAFICZNE

zeszyt $161,2020,61-80$

doi: 10.4467/20833113PG.20.008.12550

Instytut Geografii i Gospodarki Przestrzennej UJ

Komisja Geograficzna, Polska Akademia Umiejętności

Wydawnictwo Uniwersytetu Jagiellońskiego

\title{
WALORYZACJA TURYSTYCZNA I OCENA WYKORZYSTANIA POTENCJAEU DZIEDZICTWA MATERIALNEGO UKRAINY ZACHODNIEJ DLA TURYSTYKI SENTYMENTALNEJ
}

\author{
Natalia Tomczerwska-Popowycz
}

\section{Potential of material cultural heritage of the Western Ukraine, its valorisation and evaluation of the use for sentimental tourism}

Abstract: The article presents a valorisation of material cultural heritage for sentimental tourism of Poles and an analysis of the use of this potential in tourist offer. The analysis of values included defensive buildings and residences, religious buildings, cemeteries, as well as other architectural and technical monuments that can be used for the purposes of Polish sentimental tourism in the Western Ukraine, a territory that belonged to the Second Polish Republic. The analysis based on the point bonitation method showed that the Lviv and Ternopil regions have the greatest potential. However, the tourist offer of Polish travel agencies to the Western Ukraine covers only part of the potential of Polish cultural heritage.

Keywords: tourist valorisation, sentimental tourism, Eastern Borderlands, Western Ukraine

Zarys treści: W artykule przedstawiono waloryzację materialnego dziedzictwa kulturowego dla turystyki sentymentalnej Polaków oraz przeprowadzono analizę wykorzystania tego potencjału w ofercie turystycznej. Analiza walorów objęła obiekty obronne i rezydencje, obiekty sakralne, 
cmentarze, a także inne zabytkowe obiekty architektoniczne i techniczne, które mogą być wykorzystane na cele polskiej turystyki sentymentalnej na obszarze Ukrainy Zachodniej, który należał do II Rzeczpospolitej. Ocena metodą bonitacji punktowej wykazała, że największy potencjał posiada obwód lwowski oraz tarnopolski. Natomiast oferta turystyczna polskich biur podróży na Ukrainę Zachodnią obejmuje tylko część potencjału polskiego dziedzictwa kulturowego.

Stowa kluczowe: waloryzacja turystyczna, turystyka sentymentalna, Kresy Wschodnie, Ukraina Zachodnia

\section{Wprowadzenie}

Szeroko rozumiane wschodnie i południowo-wschodnie pogranicze Rzeczpospolitej zarówno w polskiej literaturze, jak i w świadomości społecznej jest powszechnie określane jako Kresy (Kieniewicz 1991). Jest to pojęcie nie tylko geograficzne, ale również polityczne, kulturowe, a nawet mityczne. Pojęcia kresów nie można traktować jako synonimu pogranicza, ponieważ nie każde pogranicze jest kresami. Są nimi natomiast obszary położone poza pierwotnym terytorium państwa, przyłączone najczęściej na drodze podboju, sukcesji lub unii. To tereny wielokulturowe, o bardzo złożonych stosunkach etnicznych, politycznych, społecznych (Barwiński 2002, 2008; Koter 1997). Takim obszarem dla Polski jest obecna Ukraina Zachodnia, której znaczna część w okresie międzywojennym należała do II Rzeczpospolitej.

W związku z układem jałtańskim z 1945 r. powojenne zmiany sprawiły, że znaczny obszar wschodniej części państwa polskiego znalazł się w obrębie obecnych Litwy, Białorusi oraz Ukrainy. Po II wojnie światowej w skład Związku Radzieckiego weszły tereny, na których od wieków żyli m.in. Polacy, Żydzi, Czesi, Ormianie. Uprawiali oni ziemie, budowali miasta, świątynie, tworzyli dzieła sztuki, nauki oraz techniki. Rządy postrzegały mniejszości narodowe (w tym Polaków) jako element niepewny politycznie, który należy usunąć. $Z$ tego powodu w latach 40. i 50. XX w. miały miejsce przymusowe przesiedlenia ludności polskiej ze wschodnich terenów II Rzeczpospolitej (wtedy były to tereny Związku Socjalistycznych Republik Radzieckich). Jednym ze skutków II wojny światowej były masowe deportacje przedstawicieli wszystkich mniejszości narodowych zamieszkujących II Rzeczpospolitą (Snyder 2002; Urban 2007).

Repatriacje i przesiedlenia Polaków przez władze Związku Radzieckiego w czasie wojny i po jej zakończeniu sprzyjały rozwojowi w późniejszym okresie turystyki sentymentalnej, czyli podróży w celu powrotu do miejsca: urodzenia, dzieciństwa, młodości lub śmierci bliskiej osoby.

Definicje „turystyki sentymentalnej” są związane z emocjami, poszukiwaniem tożsamości i wartości. Jędrysiak (2008) uważa, że turyści w ramach turystyki 
sentymentalnej odwiedzają miejsca pobytu Wielkich Polaków. Kuzyk (2011) nie tylko definiuje ten rodzaj turystyki jako odwiedzanie ziem rodzinnych, lecz także podkreśla, że podstawą wyjazdu są uczucia, emocje i nostalgia. Kilka powodów wyjazdów na Kresy Wschodnie związanych z sentymentem podają Cynarski i Cynarska (2009, s. 208): „1) potrzeba odwiedzenia miejsc znaczących dla polskiej kultury i historii oraz miejsca pobytu Wielkich Polaków; 2) związek z utrwalonymi w literaturze pięknej latami potęgi i chwały (zwłaszcza w Trylogii Henryka Sienkiewicza) z polskim etnosem i rycerskim etosem; 3) współczucie dla polskiej grupy narodowej pozostałej na ziemiach przodków i będącej teraz w wyniku zmiany przebiegu granic mniejszością". Są to motywy związane ze zwiedzaniem polskiego dziedzictwa na ziemiach Ukrainy Zachodniej. Szczegółową analizę oraz pojmowanie pojęcia „turystyka sentymentalna” i pokrewnych można znaleźć w artykule Tomczewskiej-Popowycz (2016).

Celem niniejszej pracy jest waloryzacja i analiza wykorzystania potencjału turystycznego materialnego dziedzictwa kulturowego dla turystyki sentymentalnej na Ukrainie Zachodniej.

Do tej pory została opublikowana waloryzacja turystyczna tylko obwodu iwanofrankiwskiego ${ }^{1}$, ze szczególnym uwzględnieniem możliwości uprawiania sportów zimowych (na podstawie danych z 2013 roku; Blagun, Gonak 2015). Przeprowadzono także waloryzację odcinka szlaku oraz inwentaryzację pojedynczych zabytkowych obiektów. Do najnowszych publikacji należy Waloryæacja i ocena potencjatu turystyczno-kulturowego Lwowskiej Drogi sw. Jakuba Via Regia, odcinek Lwów-Szeginie (Mróz 2019). Szczególne miejsce w literaturze przedmiotu poświęcono obiektom sakralnym obwodu lwowskiego (Golodjuk 2016; Jasieńko i in. 2009; Ostrowski 2006). Jedno opracowanie odnosi się do waloryzacji potoków górskich Karpat Wschodnich m.in. w kontekście geoturystyki (Wierzbicki 2010). Publikacje, które dotyczą atrakcyjności turystycznej mniejszych obszarów lub poszczególnych miejscowości Ukrainy Zachodniej, zostały wymienione w dalszej części artykułu.

\section{Przedmiot i metodyka badań}

W niniejszym artykule przedstawiono waloryzację turystyczną tej części Ukrainy, która należała do II Rzeczpospolitej. Badany obszar obejmuje pięć obwodów Ukrainy Zachodniej: lwowski, wołyński, rówieński, tarnopolski oraz iwanofrankiwski.

\footnotetext{
${ }^{1} \mathrm{~W}$ dalszym tekście nazwy geograficzne (miejscowości i obwodów) są zgodne z wprowadzonymi w 2012 r. przez Komisję Standaryzacji Nazw Geograficznych (posiedzenia 68-70) zmianami egzonimów (szczególną uwagę zwrócono na zapis nazwy obwodu iwanofrankiwskiego, byłego stanisławowskiego, który jest zgodny z nazwami zatwierdzonymi przez ww. komisję).
} 
Stanowi to obszar o powierzchni ponad 90 tys. $\mathrm{km}^{2}$. Oznacza to, że analiza obejmuje część szeroko rozumianych Kresów Wschodnich z pominięciem obwodu chmielnickiego, w którym znajduje się Kamieniec Podolski (który należał do I Rzeczpospolitej), a także nie uwzględnia obwodów czerniowieckiego i zakarpackiego, które także nie należały do II RP.

Zasięg terytorialny Kresów Wschodnich jest przedstawiany różnie. Początkowo za Kresy uważano wschodnie tereny I Rzeczpospolitej, które istniały do drugiej połowy XVIII w. Wtedy Królestwo Polskie sięgało od Poznania aż za Dniepr, do obwodu połtawskiego i dniepropietrowskiego na dzisiejszej Ukrainie. Południowa granica przebiegała przez następujące dzisiejsze obwody: kirowogradzki, winnicki, chmielnicki (Płoskirów), czyli wzdłuż rzeki Dniestr, i obejmowała obecną Zachodnią Ukrainę, pomijając obwód zakarpacki i czerniowiecki. Taki obszar Kresów, rozciągający się na terytorium obecnej Ukrainy, był uznawany za właściwy do końca XIX i początku XX w. (Sienkiewicz, Olczak 2006).

Obecnie za Kresy Wschodnie na Ukrainie uznaje się terytorium Polski wschodniej sprzed 1939 r. (II Rzeczpospolitej), czyli województwa: wołyńskie, tarnopolskie, stanisławowskie (iwanofrankiwskie) i lwowskie. W okresie międzywojennym województwo lwowskie obejmowało część obecnego województwa podkarpackiego, a wołyńskie część obecnego terytorium Białorusi. Sześć lat po II wojnie światowej i wytyczeniu nowych granic (15 lutego 1951 r.) doszło do zawarcia umowy o zmianie granic między Polską a Związkiem Radzieckim. Ze względu na to, że przedmiotem badań jest aktualny potencjał turystyczny dla polskich turystów sentymentalnych, zasadne jest, by objąć ramami terytorialnymi obecny podział administracyjny. Obszar objęty analizą na północy graniczy z Białorusią, na zachodzie z Polską, a na południu z Rumunią i Mołdawią. Sąsiaduje z obwodem zakarpackim na zachodzie, na południowym wschodzie z obwodem czerniowieckim, a na wschodzie z obwodami chmielnickim i żytomierskim.

Badanie przeprowadzono na kilku etapach. W pierwszym zebrano informacje na temat polskiego dziedzictwa w okresie międzywojennym. Wykorzystano literaturę zarówno z ostatnich lat, jak i z okresu międzywojennego. Zdecydowana większość badań nad polskim dziedzictwem kulturowym na Kresach Wschodnich została przeprowadzona przez historyków, którzy jednak w małym stopniu przywiązują wagę do aspektów przestrzennych rozwoju turystyki i do procesu kształtowania się bazy materialnej. Przez polskich autorów tereny Kresów Wschodnich były opisywane głównie jako przestrzenie pamięci narodowej: Brown (2013), Koper (2011, 2015), Nicieja (2006, 2012, 2015, 2017).

Ważnym źródłem informacji faktograficznej i krajoznawczej w II Rzeczpospolitej są: przewodniki Orłowicza (1929, 2002), foldery oraz informatory Ligi Popierania Turystyki i Związku Popierania Turystyki, Polskiego Biura Podróży Orbis - „Informator turystyczny” (1938-1939), przewodniki, czasopisma, w tym Polskiego Towa- 
rzystwa Tatrzańskiego: „Turysta w Polsce” (1935-1938) pod redakcją Faechera (1935) i „Przegląd Turystyczny” (1925-1928, 1932-1934), Towarzystwa Rozwoju Ziem Wschodnich $(1937,1938)$, organu Związku Letniskowo-Turystycznego Powiatów i Gmin Województwa Lwowskiego „Bieszczady” - „Nasze zdroje i letniska” (1939) - oraz czasopismo naukowe „Turyzm Polski” pod redakcją Leszczyckiego (Leszczycki 1939; Tokarski 1939).

Następnie przeprowadzono badania terenowe: obserwację własną, opisy stanu obiektów, rozmowy z pracownikami branży turystycznej, pracownikami wydziałów turystyki i promocji obwodowych administracji państwowych na Ukrainie. Zebrane informacje pochodziły również od osób działających w zrzeszeniu „Zamki Tarnopolszczyzny” i Lwowskim Zrzeszeniu Rozwoju Turystyki. Wywiadów udzielili także piloci polskich i ukraińskich biur podróży, którzy realizują wycieczki na Zachodnią Ukrainę, a także ukraińscy przewodnicy, którzy przyjmują polskie grupy. Odbyły się również spotkania z osobami pochodzącymi z Kresów w związkach miłośników Kresów. W celu zebrania danych niezbędne okazały się wielokrotne wyjazdy na Ukrainę. Autorka niniejszego artykułu odwiedziła wszystkie najważniejsze miejsca turystyczne w każdym z badanych obwodów (m.in. Lwów, Żółkiew, Łuck, Dubno, Krzemieniec, Wiśniowiec, Zbaraż, Trembowlę, Zaleszczyki, Iwano-Frankiwsk). Informacje gromadzone były w latach 2014-2018.

Następny etap badań polegał na porządkowaniu danych, weryfikacji stanu zabytków i nadaniu punktacji wybranym walorom, w celu przeprowadzenia analizy metodą bonitacji punktowej. Na ostatnim etapie opracowano wyniki metodą kartograficzną, przeprowadzono analizę i wysunięto wnioski.

\section{Waloryzacja turystyczna materialnego dziedzictwa kulturowego Ukrainy zachodniej na cele turystyki sentymentalnej Polaków}

W czasie II wojny światowej oraz w czasach socjalistycznych zniszczeniu uległo wiele zabytków należących do przesiedlonych mniejszości narodowych. Niektóre ważne budowle (głównie zamki i pałace) były odnawiane w okresie Związku Radzieckiego (m. in. zamek w Olesku). Na terytorium Kresów jest ich wiele w związku z burzliwymi dziejami „przedmurza chrześcijaństwa”, jak nazywano Kresy Wschodnie (ziemie te graniczyły z Imperium Osmańskim w XVII w.). Obwód tarnopolski posiada największą liczbę obiektów obronnych na Ukrainie (Pelehatyj 2004; Sen’kivs'ka 2008). Większość zamków popadła w ruinę, jednakże wiele z nich w ostatnich latach zabezpieczono przed dalszym niszczeniem. Te będące w rękach prywatnych często są w najgorszej sytuacji, nie są odnawiane i popadają w ruinę. Ze względu na ich atrakcyjne położenie pojawiła się presja wzniesienia 
bardziej dochodowych obiektów lub własnych posiadłości właścicieli. Wiele rezydencji i pałaców, jeszcze od czasów socjalistycznych, pełni funkcje szpitali albo szkół. W licznych zamkach i pałacach znajdują się obecnie muzea (m.in. w zamku w Wiśniowcu oraz Zbarażu).

W celu przedstawienia potencjału turystycznego oraz materialnego dziedzictwa kulturowego poszczególnych regionów Ukrainy Zachodniej przeprowadzono waloryzację turystyczną metodą bonitacji punktowej. Jest to metoda ilościowa porządkowania przestrzeni, polegająca na przypisywaniu odpowiedniej liczby punktów według ustalonej skali poszczególnym walorom kulturowym. Suma punktów daje ocenę względną, lecz umożliwia także porównanie wybranych cech w przestrzeni (Duda-Seifert 2015; Tomczyk 2005; Warszyńska 1971).

Jako jednostkę badawczą przyjęto obwód, a zabytki podzielono na następujące grupy:

1. Obiekty obronne i rezydencje:

- zamek, pałac, dwór, w których funkcjonuje muzeum - 3 pkt;

- zakonserwowana ruina udostępniona turystom $-2 \mathrm{pkt}$;

- zespół pałacowy - 2 pkt;

- ruiny w złym stanie -1 pkt.

2. Inne zabytkowe obiekty architektoniczne i techniczne:

- zabytkowy zespół urbanistyczny z rynkiem - 3 pkt;

- budynek o znacznych walorach architektonicznych lub historycznych - 1 pkt;

- fragment historycznych fortyfikacji miejskich - 1 pkt;

- zabytek techniki - 1 pkt;

- pomnik lub obiekt małej architektury związany z polską historią - 1 pkt.

3. Obiekty sakralne:

- zabytkowy zespół sakralny - 3 pkt;

- obiekt sakralny o znacznych walorach architektonicznych - 2 pkt;

- inne obiekty sakralne oraz ruiny -1 pkt.

4. Cmentarze:

- cmentarz zabytkowy z ciekawymi obiektami sztuki sepulkralnej - 2 pkt;

- cmentarz, gdzie pochowano znane i ważne (przynajmniej dla lokalnej społeczności) osobistości, lub miejsce mogił zbiorowych - 2 pkt;

- inne zabytkowe cmentarze katolickie i innych wyznań (mniejszości narodowych) -1 pkt.

Przy waloryzacji poszczególnych obwodów nie brano pod uwagę miasta Lwów, którego liczne zabytki są klasą samą w sobie. Miasto ma bardzo wysoki potencjał turystyczny (Bordun, Kozolup 2018; Kuzyk, Lytvyn 2017; Savicka, Savicka 2013; Shabliy 2017) i liczne atrakcje (m.in. Wysoki Zamek, Podzamcze, Katedrę Łacińską, XIV-wieczną Katedrę Ormiańską, Basztę Prochową, Rynek, Kopiec Unii Lubelskiej, Kościoły Dominikanów i Jezuitów, Cmentarz Orląt Lwowskich i archikatedralny 
sobór św. Jura), które znajdują się w granicach Starego Miasta, wpisanego na Listę Światowego Dziedzictwa UNESCO.

Suma punktów wszystkich czterech grup pozwoliła określić potencjał turystyczny w zakresie materialnych zabytków kulturowych w następujących klasach:

- bardzo duży potencjał turystyczny: > 400 punktów,

- duży potencjał turystyczny: 250-399 punktów,

- średni potencjał turystyczny: 100-249 punktów,

- niski potencjał turystyczny: 50-99 punktów,

- bardzo niski potencjał turystyczny: $<50$ punktów.

W celu wydzielenia przedziałów klas zsumowano punkty i obliczono wartości graniczne na podstawie wartości skrajnych. Wartości te zostały podzielone na pięć przedziałów, co uwarunkowało rozpiętość klas (Sołowiej 1992; Warszyńska, Jackowski 1978).

\section{Polskie materialne dziedzictwo kulturowe na Ukrainie Zachodniej}

Społeczność polska, która mieszkała na Kresach od wielu wieków, pozostawiła po sobie liczne cmentarze katolickie i kościoły. W wielu miejscowościach nie ma już społeczności katolickich, dlatego większość starych cmentarzy jest zaniedbana. Zróżnicowany jest stan kościołów. Wiele z nich pozostaje w ruinie, część z nich po latach 90. XX w. odrestaurowano i ponownie funkcjonują jako obiekty sakralne katolickie, grekokatolickie lub cerkwie prawosławne (Quirini-Popławski, Quirini-Popławski 2006).

W 2010 r. na Dolnym Śląsku ruszyła akcja „Mogiłę pradziada ocal od zapomnienia”. Od lat uczniowie jeżdżą na Kresy, by porządkować dawne polskie cmentarze. Na Ukrainie znajdują się także mogiły zbiorowe Polaków, ofiar Ukraińskiej Powstańczej Armii. Dokładne informacje na temat pochowanych można znaleźć w pracach Hausera (2006a, b). W miastach obwodowych funkcjonują centra kultury polskiej, które z reguły opiekują się kilkoma polskimi cmentarzami znajdującymi się w pobliżu.

Obwód iwanofrankiwski (dawniej województwo stanisławowskie) położony jest w Karpatach Wschodnich wraz z najwyższym szczytem Ukrainy - Howerlą (2061 m. n.p.m.). Największą atrakcją tego obszaru są tereny górskie o wysokich walorach przyrodniczych, a zabytki kulturowe są uzupełnieniem oferty turystycznej (Hamkało, Kudła 2011). W obwodzie znajdują się dwie drewniane cerkwie wpisane na Listę Światowego Dziedzictwa UNESCO: cerkiew Świętego Ducha w Rohatyniu oraz cerkiew Narodzenia Przenajświętszej Bogurodzicy w Wierbiążu Niżnym.

Ruiny obiektów obronnych obwodu iwanofrankiwskiego z XVII w. zachowały się w Haliczu i Pniowie. Ratusze pochodzące z XIX w. można obejrzeć w Kołomyi, 
Kutach i Śniatyniu. W Haliczu zachował się cmentarz katolicki, stara synagoga, cmentarz karaimski, a także wiele domów z przełomu XIX i XX w. Dawne kościoły katolickie z XVIII w. wraz z zachowanymi fragmentami fresków można obejrzeć w Rohatyniu oraz Iwanofrankiwsku. W tym ostatnim mieście, w kościele kolegiackim pw. NMP i św. św. Andrzeja i Stanisława (sanktuarium rodowe Potockich) znajduje się obecnie muzeum zabytków sztuki sakralnej. Na ścianie, na zewnątrz kościoła, zachowało się epitafium Stanisława Potockiego poległego pod Wiedniem, ufundowane przez obywateli miasta w 200. rocznicę bitwy. W tym kościele Sienkiewicz umieścił scenę nabożeństwa żałobnego po śmierci Michała Wołodyjowskiego.

Obwód lwowski jest bardzo bogaty pod względem dziedzictwa kulturowego. Pięć miejscowości posiada zabytki wpisane na Listę Światowego Dziedzictwa UNESCO. Jest to centrum historyczne Lwowa, a także cerkwie drewniane w Potyliczu, Matkowie, Drohobyczu oraz Źółkwi. Na tym obszarze znajduje się wiele uzdrowisk (Quirini-Popławski i in. 2019), a także obiekty przemysłowe związane z wydobywaniem ropy naftowej. Południowa część obwodu znajduje się w Karpatach Wschodnich, a zachodnia na Roztoczu (więcej o atrakcyjności tych obszarów: Quirini-Popławski 2011, Szczeciński i in. 2004).

We Lwowie, Beńkowej Wiśni (zespół pałacowy Fredrów), Brodach, Busku (dawny pałac Badenich), Dobromilu, Mościskach, Olesku, Podhorcach, Pomorzanach, Rozdole, Sądowej Wiszni, Skole, Starym Siodle, Tartakowie, Tuligłowach, Złoczowie i Żółkwi możemy podziwiać obiekty obronne i pałace należące w przeszłości do znanych polskich rodów.

Warte uwagi cmentarze i obiekty religijne zachowały się nie tylko we Lwowie, ale także w Bełzie, Borysławiu, Brodach, Busku, Chyrowie, Dobromilu, Drohobyczu, Gródku Jagiellońskim, Komarnie, Krakowcu, Łopatyniu, Mościskach, Olesku, Podhorcach, Podkamieniu (klasztor Dominikanów, który nazywano „podolską Częstochową”), Pomorzanach, Rozdole, Rudkach (mauzoleum rodziny Fredrów), Samborze, Sądowej Wiśni, Skole, Sokalu, Starym Sioło, Stryju (Kornel Makuszyński urodził się i spędził swoje dzieciństwo w tym mieście), Świrzu, Tartakowie, Tuligłowach, Złoczowie, Żółkwi (więcej informacji o polskich zabytkach w obwodzie lwowskim: Aftanazy 1995; Antonjuk 2011; Hauser 2006a, b; Maciuk 2008; Nicieja 2006; Tokarski 2001; Tomczewska-Popowycz 2015).

Na terytorium obwodu tarnopolskiego znajduje się 1315 zabytków architektury, z których 180 ma status państwowy, inne są lokalne (Istoryko-kul'turni sapovidnyky Ukrai'ny...). Niektóre z nich zostały odnowione i przeznaczone na cele turystyczne. W najlepszym stanie znajduje się zamek w Zbarażu oraz zamek Wiśniowiecki. Obydwa zostały odnowione oraz otwarto w nich muzea. Najlepiej zagospodarowany jest pierwszy z nich. Zamek Wiśniowiecki mieści w sobie ekspozycje muzealne. Również w Skałacie, w wieży zamkowej funkcjonuje muzeum. Znaczna część zachowanych do dziś ruin jest zakonserwowana lub utrzymywana w miarę dobrym stanie. Należą 
do nich ruiny zamku w Krzemieńcu, Brzeżanach, Skale Podolskiej oraz Trembowli. Konserwacji podlegają także ruiny obiektów w Czortkowie, Podzameczku, Krywczach, Jazłowcu, Złotym Potoku oraz Mikulińcach. W najgorszym stanie są ruiny zamków w Czerwonogrodzie (obecnie miejscowość o takiej nazwie nie istnieje, terytoria te administracyjnie należą do Rejonu Zaleszczyckiego), Tokach, Kudryńcach, Sidorowie. W 2013 r. w związku z brakiem konserwacji ruin zamku, a także innymi czynnikami, część wieży w Czerwonogradzie pękła i zawaliła się. Innym przykładem niszczenia obiektów jest pałac w Koropcu, w którym także w 2013 r. zapadł się dach o bardzo złożonej konstrukcji (więcej o potencjale turystycznym obwodu tarnopolskiego w: Tomczewska-Popowycz 2017).

W północnej części Wołynia jest mniej śladów polskiego dziedzictwa w porównaniu z pozostałym obszarem, gdyż były tam małe skupiska Polaków. Jest to również najmniej zagospodarowany turystycznie obszar w porównaniu z pozostałymi badanymi obwodami (podobna sytuacja panowała w okresie międzywojennym; Kovalchuk 2012; Melnychuk i in. 2013). Łuck, Dubno i Ostróg posiadają najwięcej zabytków na tym obszarze i są one w dobrym stanie.

W tabeli 1 przedstawiono całościową waloryzację turystyczną tej części Ukrainy Zachodniej, która należała w okresie międzywojennym do II Rzeczpospolitej. Ryciny 1 i 2 prezentują potencjał turystyczny badanego obszaru, na który składają się walory materialnego dziedzictwa kulturowego: obiekty obronne i rezydencje, obiekty sakralne, cmentarze, a także inne zabytkowe obiekty architektoniczne i techniczne, które mogą być wykorzystane na cele polskiej turystyki sentymentalnej. Analiza walorów turystycznych wykazała, że bardzo duży potencjał turystyczny posiadają obwody lwowski i tarnopolski, natomiast pozostałe obwody mają średni potencjał turystyczny. Największa liczba obiektów obronnych i rezydencji oraz cmentarzy mieści się w obwodzie tarnopolskim, lecz pod względem liczby zabytkowych obiektów architektonicznych i technicznych oraz obiektów sakralnych przoduje obwód lwowski. Obwody rówieński i wołyński we wszystkich analizowanych kategoriach ustępują obwodom lwowskiemu i tarnopolskiemu, lecz mają przewagę w kategorii obiektów obronnych i rezydencyjnych nad obwodem iwanofrankiwskim.

Obwód wołyński wypada najgorzej pod względem liczby obiektów obronnych i pałaców na Ukrainie Zachodniej. Obwód rówieński w tej kategorii ma nieco większy potencjał turystyczny. Potencjał mierzony w odniesieniu do liczby polskich kościołów i cmentarzy na Wołyniu także jest niski. Zwiększa się on w kierunku południowym (ryc. 2). Jest to związane z uwarunkowaniami przyrodniczymi (na Polesiu Wołyńskim znajdowały się rozległe zatorfione bagna, z których ponad 25 tys. ha zostało wysuszonych dopiero w latach 70-80. XX w.; Zastawnyj, Kusiński 2003) oraz wydarzeniami historycznymi (obszar ten dłużej znajdował się pod panowaniem Imperium Rosyjskiego niż sąsiednie obwody na południu). 


\section{Legenda / Legend:}

m ruiny obiektów obronnych i rezydencji ruin of fortification or residence

四 zamki i pałace w których funkcjonuje muzeum granice obwodów / boundary of oblasts castle or palace with museum

(1. zamki i pałace niepełniące funkcji turystycznych główne drogi / main roads castle or palace with non-tourist functions ufortyfikowane miasto, w którym zachowały się

- mury miejskie oraz zamek lub pałac

fortified city with preserved city walls and a castle or palace

BIAŁORUŚ

miejsce dawnego grodu średniowiecznego /place of the former medieval strongholds

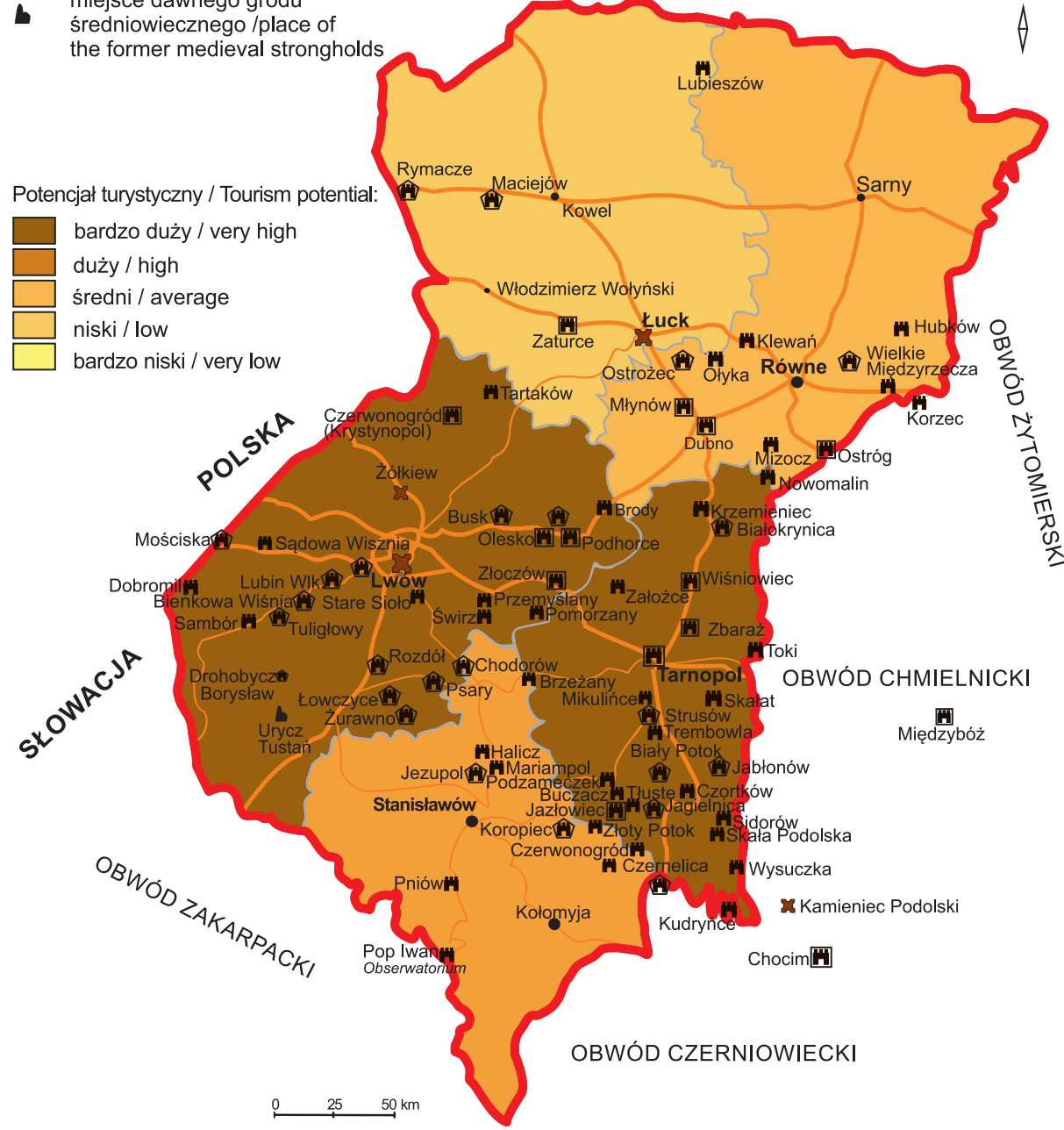

Ryc. 1. Obiekty obronne i rezydencje na badanym obszarze Ukrainy Zachodniej ${ }^{1}$

Fig. 1. Defensive objects and residences in the studied area of the Western Ukraine

\footnotetext{
${ }^{1}$ Kolor jasnożółty (bardzo niski potencjał turystyczny) nie pojawia się na badanym obszarze, lecz ze względu na przyjętą skalę waloryzacji został uwzględniony w legendzie.
} 


\section{Legenda / Legend:}

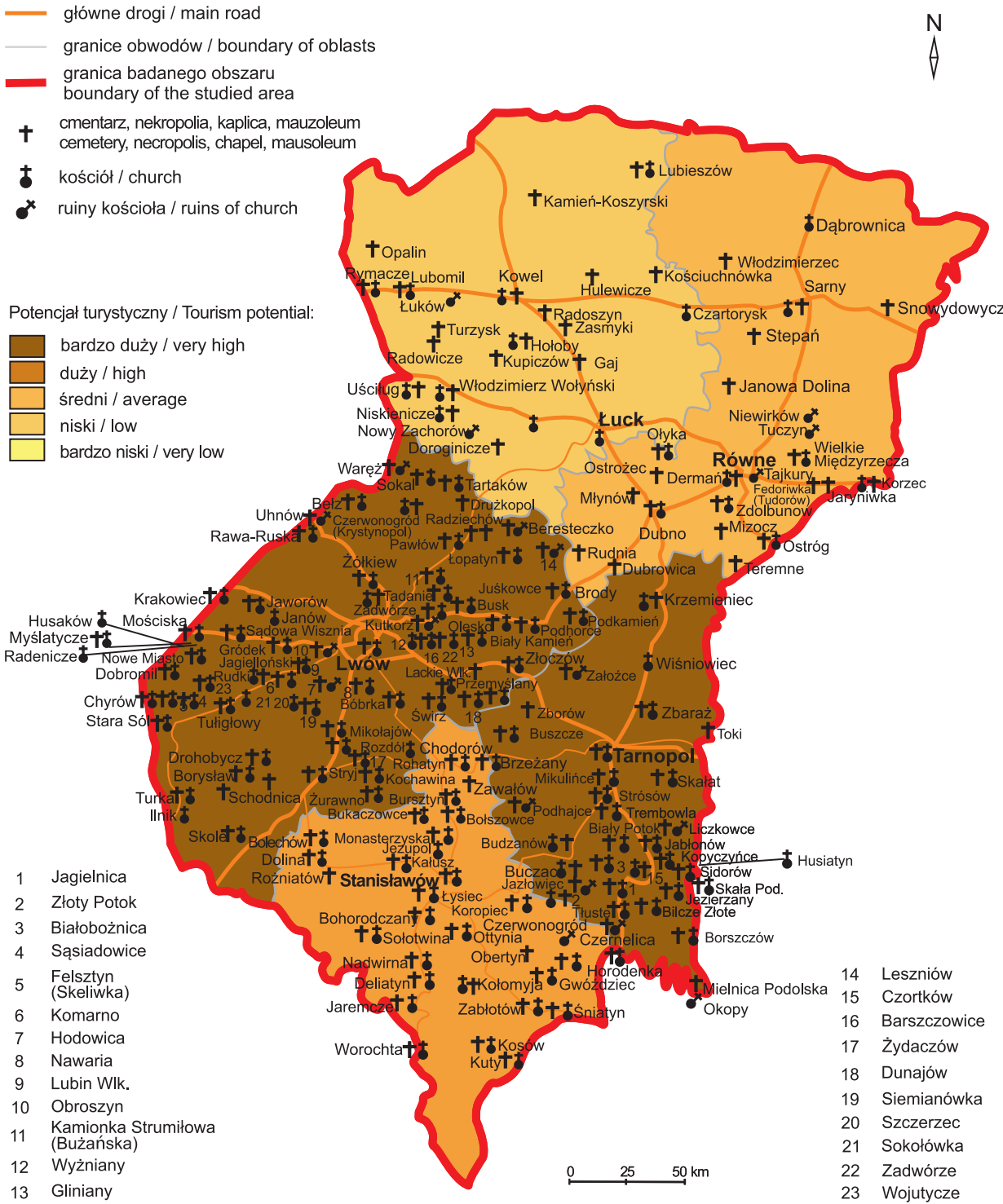

Ryc. 2. Główne kościoły katolickie (dawniej lub obecnie) i cmentarze (na których są pochowani Polacy) znajdujące się na badanym obszarze Ukrainy Zachodniej

Fig. 2. Main catholic (currently or in the past) churches and cemeteries (where Poles lay buried) located in the studied area of the Western Ukraine 
Tab. 1. Waloryzacja potencjału turystycznego materialnego dziedzictwa kulturowego Ukrainy Zachodniej według obwodów

Table. 1. Valorisation of the tourist potential of material cultural heritage of the Western Ukraine as divided into oblasts

\begin{tabular}{|l|c|c|c|c|c|}
\hline \multirow{2}{*}{ Grupa / Group } & \multicolumn{5}{c|}{ Obwód / Oblast } \\
\cline { 2 - 6 } & iwanofrankiwski & Iwowski & tarnopolski & rówieński & wołyński \\
\hline $\begin{array}{l}\text { 1. Obiekty obronne i rezydencje } \\
\text { Defensive objects and residences }\end{array}$ & 10 & 54 & 87 & 29 & 24 \\
\hline $\begin{array}{l}\text { 2. Zabytkowe obiekty architektoniczne } \\
\text { i techniczne } \\
\text { Historic architectural and technical } \\
\text { objects }\end{array}$ & 45 & 58 & 37 & 21 & 16 \\
\hline $\begin{array}{l}\text { Razem 1 i 2 } \\
\text { Total 1 and 2 }\end{array}$ & 55 & 112 & 124 & 50 & 40 \\
\hline $\begin{array}{l}\text { 3. Obiekty sakralne } \\
\text { Sacral buildings }\end{array}$ & 93 & 284 & 175 & 79 & 84 \\
\hline $\begin{array}{l}\text { 4. Cmentarze } \\
\text { Cemeteries }\end{array}$ & 38 & 91 & 107 & 21 & 24 \\
\hline $\begin{array}{l}\text { Razem 3 i 4 } \\
\text { Total 3 and 4 }\end{array}$ & 131 & 375 & 282 & 100 & 108 \\
\hline $\begin{array}{l}\text { Razem 1, 2, 3, 4 } \\
\text { Total 1, 2, 3, 4 }\end{array}$ & $\begin{array}{c}\text { średni } \\
\text { average }\end{array}$ & $\begin{array}{c}\text { bardzo wysoki } \\
\text { very high }\end{array}$ & bardzo wysoki \\
\hline $\begin{array}{l}\text { Ogólny potencjał turystyczny } \\
\text { Overall tourist potential }\end{array}$ & $\begin{array}{c}\text { średni } \\
\text { average }\end{array}$ & $\begin{array}{c}\text { średni } \\
\text { average }\end{array}$ \\
\hline
\end{tabular}

W okresie międzywojennym obwód rówieński nie należał do atrakcyjnych turystycznie, jednak miasto Równe było znane z targów. Niemal wszystkie obiekty sakralne zostały przekształcone na obiekty o innych funkcjach: sale koncertowe, magazyny; niewiele z nich przetrwało do dziś w dobrym stanie. W badanym regionie mają znaczenie obiekty nie tylko rzymskokatolickie, ale także prawosławne, które były zakładane przez polskich mecenasów jeszcze w XVIII w. W porównaniu z południową częścią Ukrainy Zachodniej w bardzo złym stanie są nieliczne cmentarze katolickie oraz synagogi, co jest związane z brakiem wspólnot, które mogłyby o nie zadbać.

Obwód wołyński jest w nieco korzystniejszej sytuacji od rówieńskiego, gdyż graniczy z Polską, a miasto obwodowe Łuck ma lepszą infrastrukturę turystyczną i znajduje się w nim słynny obiekt - zamek. Oprócz znanej i rozpoznawalnej rezydencji w Łucku w Ołyce zachował się piękny pałac barokowy, który obecnie pełni funkcję szpitala psychiatrycznego. Obiekt ten potrzebuje remontu, a wnętrza zostały mocno przekształcone. Obok mieści się okazały kościół, jednak wokół pałacu znajdują się zabudowania z czasów rządów radzieckich, które szpecą otoczenie tych unikatowych zabytków. 


\section{Analiza oferty turystycznej Ukrainy Zachodniej}

Polacy stanowią 9\% ogólnego przyjazdowego ruchu turystycznego na Ukrainie (stan na 2019 r.) (STTU 2019). Polacy nie potrzebują wizy, by przekroczyć granicę z Ukrainą. W 2016 r. na Ukrainę przyjechało ponad 13,7 mln cudzoziemców, najwięcej zaś było ich w 2008 r. - około 25 mln osób (STTU 2019). Jest to związane m.in. z niestabilną sytuacją polityczną na wschodzie państwa od 2014 r.

Przegląd ofert turystycznych biur podróży działających na polskim rynku na początku 2019 r. wykazał, że największe biura turystyczne, takie jak Itaka, Tui Poland, Wezyr, Almatur, Eccoholiday, nie mają w swojej ofercie wycieczek na Ukrainę. Jedynie Biuro Podróży Rainbow oferuje wycieczkę „Na zielonej Ukrainie”, której trasa obejmuje m.in. Lwów, Zbaraż, Tarnopol, Buczacz, Czerniowce, Chocim, Kamieniec Podolski, Winnicę i Kijów. Produkt turystyczny BP Rainbow „Z Kresów do bezkresów” obejmuje Litwę, Białoruś i Ukrainę (Źółkiew, Lwów i Łuck).

W 2019 r. na rynku usług turystycznych w ofercie wycieczek na Ukrainę przodowały niewielkie biura podróży, które specjalizują się w wycieczkach na wschód. Były to m.in. Bezkresy, Bieszczader, PTT „Chortycia”, Quand, Wilejka. Te biura turystyczne oferują wycieczki głównie na Zachodnią Ukrainę, przede wszystkim do Lwowa, ale także w Bieszczady Wschodnie i na Huculszczyznę, oraz do Truskawca. Po 2014 r. liczba ofert wycieczek na Ukrainę zdecydowanie się zmniejszyła, jednak już w 2018 r. wróciła do stanu sprzed 2014 r. (aneks I). Oznacza to, że niestabilna sytuacja polityczna Ukrainy miała krótkotrwały negatywny wpływ na przyjazdowy ruch turystyczny w zachodniej części kraju.

W ofercie turystycznej skierowanej na Ukrainę Zachodnią zdecydowanie dominuje turystyka kulturowa. Najbardziej popularnym kierunkiem takich wypraw jest Lwów. Także często odwiedzana jest Żółkiew w związku z przebiegiem dróg o znaczeniu międzynarodowym. Podczas kilkudniowych wycieczek do Lwowa zwiedza się także obiekty „Złotej podkowy”. Jest to szlak turystyczny obejmujący słynne zamki w Olesku, Podhorcach i Złoczowie, a także inne obiekty obronne w Starym Siole, Świrzu, Pomorzanach, Białym Kamieniu, Busku, które raczej nie widnieją w ofercie. Na drugim miejscu według popularności odwiedzanych miejsc, znajduje się Kamieniec Podolski wraz z pobliskim Chocimiem i Okopami Świętej Trójcy. Organizowane są również podróże na Wołyń, szczególnie do Krzemieńca, gdzie znajduje się jedyne na świecie muzeum Juliusza Słowackiego. W drodze do Krzemieńca uczestnicy wycieczek często zbaczają w stronę Zbaraża oraz Wiśniowca. Na Wołyniu miastami wyróżniającymi się pod względem turystycznym są Łuck oraz Dubno. Innym ważnym regionem turystycznym jest Huculszczyzna wraz z Kołomyją, Kosowem, Jaremczem i Worochtą (te ostatnie to znane kurorty). Czasami na trasie wycieczek znajduje się także Drohobycz, znany jako miasto, w którym mieszkał Bruno Schulz. Niemal wszystkie proponowane wycieczki to standardowe oferty 
objazdowe, których celem jest poznanie dziedzictwa kulturowego. Wyjątkiem są wyjazdy na Huculszczyznę, gdzie turystyka kulturowa jest połączona z turystyką aktywną, a także wycieczki do Truskawca, odbywane głównie w celach zdrowotnych. Typowe oferty wyjazdu na Kresy Wschodnie obejmują najdłużej 8 dni. Koszt wycieczek jest dla Polaków przystępny (aneks I).

Bogata oferta ww. biur podróży dotyczy tylko części ważnych miejsc historycznych. Brakuje jeszcze obiektów i terenów silnie powiązanych z Polakami i ich historią, m.in. miejsc związanych z rodziną Fredrów (Bieńkowa Wiśnia, Rudki) oraz miejscowości znajdujących się na międzynarodowym szlaku naftowym (m.in. Borysław, rejon samborski i drohobycki). Wycieczki na Huculszczyznę nie obejmują miejscowości Śniatyń. W ofertach próżno szukać następujących miejscowości: w obwodzie lwowskim - Dobromila, Hyrowa, Skola, Tuligłowów, tarnopolskim - Koropca, Kudryńców, Potoku Złotego, Toków. Brak jest ofert związanych ze spływami Zbruczem, Dniestrem czy Słuczem (m.in. Hubków). W związku z tym można uznać, że oferta turystyczna nie wykorzystuje w pełni analizowanego potencjału turystycznego.

Polskie biura podróży często korzystają z usług przewodników miejskich we Lwowie. Ukraińskie biura podróży raczej nie posiadają polskojęzycznych wersji swoich stron internetowych, a w konsekwencji produktów turystycznych skierowanych bezpośrednio do Polaków. Z rozmowy z pracownikami polskich biur turystycznych wynika, że często problemem jest komunikacja z organizatorami turystyki po stronie ukraińskiej, szczególnie z personelem obiektów noclegowych o niższym standardzie.

Jak wynika z rozmów z pracownikami obiektów noclegowych, przyjeżdżający Polacy zwracają się czasami z prośbą o pomoc w poszukiwaniu lokalizacji związanych z przodkami, pokazują zdjęcia rodzinne i chcą znaleźć uwiecznione na nich miejsca, jednak pracownikom recepcji często bardzo trudno jest pomóc takim osobom, gdyż nie posiadają oni odpowiednich kompetencji.

\section{Podsumowanie}

Nie sposób ocenić walorów turystycznych, które są bardzo ważne dla Polaków, gdyż każdy z nich stanowi odrębną wartość dla poszczególnych grup lokalnych, szczególnie dla pierwszego pokolenia osób przesiedlonych.

Zaniechanie typowego dla władz radzieckich traktowania dziedzictwa kulturowego mniejszości narodowych jako kłopotliwego dziedzictwa (Banaszkiewicz, Semik 2019) i wyeksponowanie miejsc wspólnych w historii Polski i Ukrainy (nawet z pominięciem wydarzeń kontrowersyjnych) pomogłoby budować most porozumienia i zwiększać świadomość historyczną po obu stronach.

$Z$ pewnością obiekty kulturowe wymagają dalszego zagospodarowania. Dotyczy to szczególnie ekspozycji muzealnych, które w małym stopniu lub w ogóle 
nie przedstawiają ważnych wydarzeń historycznych z czasów I i II Rzeczpospolitej. Przykładem może być zamek w Zbarażu (znany z powieści Sienkiewicza Ogniem i mieczem), podczas zwiedzania którego nie dowiemy się, że pojawia się on w książkach polskiego noblisty. Tablice informacyjne i znaki turystyczne są w języku ukraińskim, rosyjskim i angielskim, nie ma zaś informacji w języku polskim.

W momencie rozpoczęcia badań (przełom 2014 i 2015 r.), na Ukrainie Zachodniej toczył się konflikt zbrojny z Federacją Rosyjską, co spowodowało, iż polskie biura podróży ograniczyły prawie do zera liczbę ofert turystycznych z wyjazdami na Ukrainę. Jednak od 2016 r., kiedy media już prawie nie nagłaśniały wydarzeń wojennych na Ukrainie, ruch turystyczny zaczął wracać do stanu poprzedniego, a ceny na Ukrainie były zdecydowanie niższe w związku ze spadkiem kursu hrywny. Dopiero w latach 2017-2018 ruch turystyczny z Polski wrócił do stanu poprzedniego, jednak wielu walorów Ukrainy nie ujęto w propozycjach biur turystycznych.

Warto wykorzystać położenie badanego obszaru, rozwijać infrastrukturę turystyczną, szczególnie dostępność komunikacyjną, w tym stan nawierzchni drogowej. Organizacja międzynarodowych wydarzeń promujących region, a także podkreślanie wspólnej historii kilku narodów, a nie jej wymazywanie, pomogłyby przyciągnąć turystów zza granicy.

\section{Literatura:}

Aftanazy R., 1995, Dzieje rezydencji na dawnych kresach Rzeczypospolitej, Województwo ruskie, ziemia halicka i lwowska, Zakład Narodowy im. Ossolińskich, Wrocław.

Antonjuk D., 2011, Sto p'jatdesjat pol's'kyh zamkiv ta rezydencijv Ukrai'ni, Chastyna I, Grani-T, Kyiv.

Banaszkiewicz M., Semik Z., 2019, Schrony w Nowej Hucie jako ktopotliwe dziedzictwo:pomiędzy edukacjq a rozrywkq, Turyzm/Tourism, 29 (1), 7-15.

Barwiński M., 2002, Pogranicze w ujęciu geograficzno-socjologicznym - zarys problematyki, Acta Universitatis Lodziensis Folia Geographica Socio-Oeconomica, 4, 11-23.

Barwiński M., 2008, Konsekwencje zmian granic i przeksztatceń politycznych po II wojnie swiatowej na liczebność i rozmieszczenie Ukraińców, Łemków, Biatorusinów i Litwinów w Polsce, [w:] P. Eberhardt (red.), Problematyka geopolityczna ziem polskich, IGiPZ PAN, Prace Geograficzne, 218, Warszawa, 217-235.

Blagun I.S., Gonak I.M., 2015, Valoryzacija regional'nogo turystychnogo prostoru, Biznes Inform, (1), 104-110.

Bordun O., Kozolup M., 2018, SWOT Analysis of Lviv Tourist Destination and Key Indicators of its Sustainability, Studia Periegetica, 4 (24), 37-58.

Brown K., 2013, Kresy: biografia krainy, której nie ma: jak zniszczono wielokulturowe pogranicze, Wydawnictwo Uniwersytetu Jagiellońskiego, Kraków. 
Cynarski W.J., Cynarska E., 2009, Turystyka sentymentalna Polaków na Kresy wschodnie, Ido-Ruch dla Kultury, 9, 201-209.

Duda-Seifert M., 2015, Kryteria oceny atrakcyjności turystycznej obiektów architektury w świetle literatury, Turystyka Kulturowa, 4, 74-88.

Faecher S., 1935, Turysta w Polsce, nr 2, Rok I, Polskie Towarzystwo Tatrzańskie, Polski Związek Narciarski i Polski Związek Kajakowy, Kraków-Warszawa.

Golodjuk N., 2016, Pravoslavni monastyri Rivnens'koi', Ternopil's'koi' ta Volyns'koi' oblastej jak ob'jekty palomnyctva ta religijnogo turyzmu, Religija ta socium, (3-4), 228-233.

Hamkało M., Kudła, N., 2011, Karpaty Ukrainskie jako region turystyczny - uwarunkowania i mo:́liwości rozwoju, Prace Geograficzne, 125, 63-75.

Hauser Z., 2004, Ilustrowany przewodnik po sabytkach Galicji Wschodniej: lwowskie, Lwów, stanistawowskie, Burchard, Warszawa.

Hauser Z., 2006a, Ilustrowany preewodnik po sabytkach na Wotyniu i Podolu, Burchard, Warszawa.

Hauser Z., 2006b, Podróże po cmentaræach Ukrainy - dawnej Matopolski Wschodniej, Księgarnia Akademicka, 2, Kraków.

Informatorturystyczny, 1933, Związek Polskich Towarzystw Turystycznych w Polsce, Warszawa. Istoryko-kul'turni sapovidnyky Ukrai'ny, Kyi'v, Dovidnyk.

Jasieńko J., Kadłuczka A., Sroczyńska J., Kadłuczka K., Nowak T., 2009, Kolegiata św. Trójcy w Otyce na Wotyniu (Ukraina) - rejestracja stanu zachowania, problemy konserwatorskie, Wiadomości Konserwatorskie, 427-436.

Jędrysiak T., 2008, Turystyka kulturowa, Polskie Wydawnictwo Ekonomiczne, Warszawa.

Kieniewicz S., 1991, Kresy: præemiany terminologicæne w perspektywie dziejowej, Gebethner i S-ka, Warszawa.

Koper S., 2011, Ukraina, præewodnik historyczny: tragiczne dzieje:polskieślady, Bellona, Warszawa. Koper S., 2015, Moje Kresy sentymentalne, Bellona, Warszawa.

Koter M., 1997, Kresy państwowe - geneza $i$ wtaściwości w świetle doświadczeń geografii politycznej, [w:] K. Handke (red.), Kresy - pojęcie i ræeczywistość, Slawistyczny Ośrodek Wydawniczy, Warszawa, 9-52.

Kovalchuk T., 2012, Turystychnyj ruh na Volyni u mizhvojennyj period, Krajeznavstvo, (2), 112-120.

Kuzyk S., 2011, Teoretychni problemy turyzmu: suspil'no-geografichnyj pidhid, Vydavnychyj centr LNU im. Ivana Franka, L’viv.

Kuzyk S., Lytvyn D., 2017, Specific features of using historical and cultural resources of the UkrainianPolish borderland for tourism purposes, Chasopys social'no-ekonomichnoi geografii, 23 (2), 53-59.

Lato we dworach Ziem Wschodnich, 1938, Sekcja Turystyki Towarzystwa Rozwoju Ziem Wschodnich, Warszawa.

Leszczycki S., 1939, Z geografii uzdrowisk Polski, Turyzm Polski, 5, II, 96-102.

Maciuk O., 2008, Zamki i twierdze Ukrainy Zachodniej. Wędrówki historyczne, Centrum Europy, Lwów. 
Melnychuk M., Ujevych S., Chernec V., Gladych L., Bezsmertnjuk T., 2013, Suchasnyj stan i perspektyvy rozvytku turystychnoi' ta rekreacijnoi' dijal'nosti Volyns'koi oblasti, Naukovi zapysky Ternopilskogo nacional'nogo pedagogichnogo universytetu imeni Volodymyra Gnatjuka. Ser.: Geografija, (2), 101-115.

Mróz F., 2019, Waloryzacja i ocena potencjatu turystyczno-kulturowego Lwowskiej Drogi św. Jakuba Via Regia (odcinek Lwów-Szeginie), [w:] M. Apollo, M. Krupska-Klimczak (red.), Poland and Ukraine: Problems and prospect, Wydawnictwo Naukowe Uniwersytetu Pedagogicznego w Krakowie, 97-152.

Nicieja S., 2006, Twierdze kresowe Rzeczypospolitej: historia, legendy, biografie, Wydawnictwo Iskry, Warszawa.

Nicieja S., 2012, Kresowa Atlantyda: historia i mitologia miast kresowych. Lwów, Stanistawów, Tarnopol, Brzesany, Borystaw, Wydawnictwo MS, 1, Opole.

Nicieja S., 2015, Kresowa Atlantyda: historia i mitologia miast kresowych., Drohobycz, Majdan, Schodnica, Stawesko, Turka, Wydawnictwo MS, 7, Opole.

Nicieja S., 2017, Kresowa Atlantyda: historia i mitologia miast kresowych., Krzemieniec, Kisielin, Śniatyn, Zatucze, Pików, Marynki, Aleksandrówka, Wydawnictwo MS, 9, Opole.

Orłowicz M., 1929, Ilustrowany przewodnik po Wołyniu: z 101 ilustracjami i mapkq województwa, Wołyńskie Towarzystwo Krajoznawcze i Opieki nad Zabytkami Przeszłości, Łuck.

Orłowicz M., 2002, Ilustrowany præewodnik po Galicyi, Bukowinie, Spisæu, Orawie i Ślasku Cieszyńskim, Ruthenus, Krosno.

Ostrowski J.K., 2006, Inwentaryzacja sabytkow sætuki sakralnej na kresach wschodnich - wwagi kombatanta, Biuletyn Historii Sztuki, 68 (2), 269-272.

Pelehatyj J., 2004, Arhitektura Ternopil'shhyny, Ternopil's'kyj encyklopedychnyj slownyk, 4, Vydavnycho-poligrafichnyj kombinat „Zbruch”, 51-55.

Quirini-Popławski Ł., 2011, Walory przyrodnicze i kulturowe jako podstawa atrakcyjności turystycznej Beskidow Wschodnich na obsæarze obwodow lwowskiego i iwanofrankowskiego (Ukraina), Prace Geograficzne, 125, 129-145.

Quirini-Popławski Ł., Kudła N., Rytynski M., 2019, Turystyka w sowieckich Karpatach. Infrastruktura noclegowa dla turystyki kwalifikowanej w latach 70. $i$ 80. XX wieku na obszarze Karpat Wschodnich (obwody lwowski i iwanofrankowski), Turyzm/Tourism, 29 (2), 119-128.

Quirini-Popławski Ł., Quirini-Popławski R., 2006, Losy swiatyń rzymskokatolickich w Beskidach Wschodnich po 1939 r., Peregrinus Cracoviensis, 17, 69-84.

Savicka O., Savicka N., 2013, Strategija rozvytku turystychnoi' industrii'v Ukrai'ni: regional'ni aspekty, Visnyk Nacional'nogo universytetu L'vivs'ka politehnika. Problemy ekonomiky ta upravlinnja, (754), 68-74.

Sen'kivs'ka G.J., 2008, Pam'jatkoohoronna robota der whavnyh struktur i gromads'kyh organizacij na Ternopil'shhyni (Druga polovyna XX stolittja), Zbirnyk naukovyh prac' Harkivs'kogo nacional'nogo pedagogichnogo universytetu imeni G.S. Skovorody. Serija: Istorija ta geografija, 31, 61-68. 
Shabliy O., 2017, Human and geographical analysis of historical and cultural heritage of Lviv, Journal of Geography, Politics and Society, 7 (2), 48-63.

Sienkiewicz W., Olczak E., 2006, Ilustrowany atlas historii Polski, 1, Demart, Warszawa.

Snyder T., 2002, Memory of sovereignty and sovereignty over memory: Poland, Lithuania and Ukraine, 1939-1999, [w:] J. W. Muller (red.), Memory and power in post-war Europe. Studies in the presence of the past, Cambridge University Press, 39-58.

Sołowiej D., 1992, Podstawy metodyki oceny środowiska przyrodniczego człowieka, PWN, Warszawa.

Szczeciński R., Jagusiewicz A., Kowesznikow W., Lozynskij R., Malska M., Zinko J., 2004, Potencjat turystyczny Ukrainy Zachodniej, Instytut Turystyki, Warszawa.

Tokarski J., 2001, Ilustrowany praewodnik po sabytkach kultury na Ukrainie, Burchard, 2, Warszawa.

Tokarski Z., 1939, Zagospodarowanie turystyczne Karpat Polskich, Turyzm Polski, nr 4.

Tomczewska-Popowycz N., 2015, Zamki i patace Ukrainy atrakcja dla turystów z Polski, Turystyka Kulturowa, 6, 36-50.

Tomczewska-Popowycz N., 2016, Wokót definicji turystyki sentymentalnej i etnicznej, Folia Turistica, 40, 47-69.

Tomczewska-Popowycz N., 2017, Problemy wykorzystania potencjatu turystycznego Kresów Wschodnich na Ukrainie na przyktadzie obwodu Tarnopolskiego, Turystyka Kulturowa, 2, 141-160.

Tomczyk A., 2005, Atrakcyjnośc turystyczna regionu - aspekt teoretyczny oras praktyczne zastosowanie jednej z metod jej oceny, Problemy Turystyki, 28 (3-4), 19-35.

Urban T., 2007, Utracone ojczyzny. Wypędzenia Niemców i Polaków w XX wieku, Czytelnik, Warszawa.

Wakacje we dworach Ziem Wschodnich, 1937, Sekcja Turystyki Towarzystwa Rozwoju Ziem Wschodnich, Warszawa.

Warszyńska J., 1971, Waloryzacja miejscowości z punktu widzenia atrakcyjności turystycznej, Prace Geograficzne, 49, 14-35.

Warszyńska J., Jackowski A., 1978, Podstawy geografii turyzmu, PWN, Warszawa.

Wierzbicki G., 2010, Geomorfologic«ne kartowanie koryta jako element przyrodnicæej waloryzacji potoków górskich na przyktadzie Karpat Wschodnich, Infrastruktura i Ekologia Terenów Wiejskich, 9, 5-15.

Zastawnyj F., Kusiński W., 2003, Ukraina: przyroda - ludność - gospodarka, Wydawnictwo Akademickie Dialog, Warszawa.

Znak I.B., 2019, Vidtvorennja arhitekturno-prostorovoi' struktury monastyriv, Wydawnictwo Chynu Svjatogo Vasylija Velykogo Zahidnoi' Ukrai'ny.

\section{Strony internetowe:}

Biuro podróży Bezkresy, http://www.bezkresy.pl/country,5,Ukraina.html (dostęp: 31.03.2019).

Biuro Podró:y Bieszczader, http://bieszczader.pl/ukraina/wycieczki-na-kresy/ (dostęp:31.03.2019).

Biuro Podróży Quand, http://www.quand.com.pllfiles/katalog_quand_2017.pdf(dostęp: 31.03.2019). 
Biuro podró:y Wilejka, http://www.wilejka.plloferta_opis/Szlakiem\%20Bohater\%C3\%B3w\%20 Trylogii\%202018 (dostęp: 31.03.2019).

http://www.kresy.com/lista_wycieczek.php?kat=Ukraina (dostęp: 31.03.2019).

http://www.top.turystyka.pl/?s=oferta\&id=187 (dostęp: 1.03.2019).

http://www.wycieczkinakresy.pl/index.php?page=news (dostęp: 31.03.2019).

STTU, 2019, State Statistics Service of Ukraine, (Derzhavna Sluzhba Statistiki Ukrayiny) http:// www.ukrstat.gov.ua/ (dostęp: 10.03.2020).

Natalia Tomczewska-Popowycz

Uniwersytet Ślaski

Wydziat Nauk Przyrodniczych

Instytut Geografii Spoteczno-Ekonomicznej i Zagospodarowania Przestrzennego

ul. Będzińska 60, 41-200 Sosnowiec

natalia.tomczewska-popowycz@us.edu.pl 
Aneks. I. Oferta polskich biur podróży organizujących wycieczki na Kresy Wschodnie na Ukrainie w 2019 r.

Annex I. Offer of Polish travel agencies organizing trips to the Eastern Borderlands in Ukraine in 2019

\begin{tabular}{|c|c|c|c|c|}
\hline $\begin{array}{l}\text { Biuro podróży } \\
\text { Travel agency }\end{array}$ & $\begin{array}{l}\text { Czas } \\
\text { trwania } \\
\text { (dni) } \\
\text { Duration } \\
\text { (days) }\end{array}$ & $\begin{array}{l}\text { Nazwa wycieczki } \\
\text { Title of the tour }\end{array}$ & $\begin{array}{l}\text { Główne zabytki } \\
\text { Main sights }\end{array}$ & $\begin{array}{l}\text { Cena } \\
\text { Price }\end{array}$ \\
\hline \multirow{9}{*}{$\begin{array}{l}\text { Biuro } \\
\text { Turystyczne } \\
\text { Bezkresy, } \\
\text { Warszawa. }\end{array}$} & 4 & Lwów i Złota Podkowa & Lwów, Olesko, Podhorce, Złoczów, Świrz & $800 \mathrm{zł}$ \\
\hline & 4 & Tylko we Lwowie & Lwow, Żółkiew & $870 \mathrm{zł}$ \\
\hline & 4 & Kresy 4 dni & $\begin{array}{l}\text { Olesko, Podhorce, Krzemieniec, Zbaraż, Mikulińce, } \\
\text { Trembowla, Skała Podolska, Jaskinia Kryształowa, } \\
\text { Kamieniec Podolski, Okopy św. Trójcy, Chocim, } \\
\text { Kołomyja, Stanisławów, Drohobycz. }\end{array}$ & $\begin{array}{l}369 \text { zł }+ \\
30 \text { euro }\end{array}$ \\
\hline & 5 & Krzemieniec i Lwów & $\begin{array}{l}\text { Łuck, Dubno, Krzemieniec, Poczajów, Podhorce, } \\
\text { Olesko, Lwów, Żółkiew }\end{array}$ & $960 \mathrm{zł}$ \\
\hline & 5 & $\begin{array}{l}\text { Szlakiem twierdz } \\
\text { kresowych }\end{array}$ & $\begin{array}{l}\text { Łuck, Dubno, Krzemieniec, Wiśniowiec, Zbaraż, } \\
\text { Trembowla, Skała Podolska, Kamieniec Podolski, } \\
\text { Okopy Św. Trójcy, Chocim, Jazłowiec, Buczacz, } \\
\text { Podhajce, Brzeżany, Świrz, Lwów, Żółkiew } \\
\end{array}$ & $960 \mathrm{zł}$ \\
\hline & 6 & $\begin{array}{l}\text { Huculszczyzna - } \\
\text { Karpaty Wschodnie }\end{array}$ & $\begin{array}{l}\text { Truskawiec, Drohobycz, Stanisławów, Kołomyja, } \\
\text { Kosów, Huta, Jaremcze, Worochta, Wierchowyna, } \\
\text { Halicz, Rohatyn, Świrz, Lwów }\end{array}$ & $1360 \mathrm{zł}$ \\
\hline & 6 & $\begin{array}{l}\text { Twierdze Kresowe, } \\
\text { Czerniowce i Lwów }\end{array}$ & $\begin{array}{l}\text { Łuck, Dubno, Krzemieniec, Wiśniowiec, Zbaraż, } \\
\text { Trembowla, Skała Podolska, Kamieniec Podolski, } \\
\text { Okopy św. Trójcy, Chocim, Czerniowce, Zaleszczyki, } \\
\text { Jazłowiec, Buczacz, Podhajce, Brzeżany, Rohatyn, } \\
\text { Świrż, Lwów, Żółkiew }\end{array}$ & $995 \mathrm{zł}$ \\
\hline & 8 & $\begin{array}{l}\text { Szlakiem Ogniem } \\
\text { i Mieczem }\end{array}$ & $\begin{array}{l}\text { Lwów, Świrz, Stanisławów, Kołomyja, Horodenka, } \\
\text { Czerwonogród, Zaleszczyki, Kamieniec Podolski, } \\
\text { Okopy Św. Trójcy, Chocim, Skała Podolska, } \\
\text { Jazłowiec, Buczacz, Trembowla, Tarnopol, Zbaraż, } \\
\text { Wiśniowiec, Krzemieniec, Poczajów, Podhorce, } \\
\text { Olesko, Żółkiew }\end{array}$ & 1560 zł \\
\hline & 8 & $\begin{array}{l}\text { Przez Ruś na Ukrainę, } \\
\text { Wołyń, Kijów }\end{array}$ & $\begin{array}{l}\text { Włodzimierz Wołyński, Łuck, Ołyka, Klewań, } \\
\text { Równe, Ostróg, Międzyrzecz Ostrogski, Korzec, } \\
\text { Żytomierz, Berdyczów, Kijów, Kaniów, Korsuń, } \\
\text { Biała Cerkiew, Humań, Tulczyn, Niemirów, Winnica, } \\
\text { Latyczów, Międzybórz, Zbaraż, Wiśniowiec, Krze- } \\
\text { mieniec, Dubno }\end{array}$ & $1670 \mathrm{zł}$ \\
\hline \multirow{3}{*}{ PB Bieszczader } & 1 & Lwów & Cmentarz Łyczakowski, starówka, opera & $130 \mathrm{zł}$ \\
\hline & 3 & Lwów i Złota Podkowa & Lwów, Olesko, Podhorce, Złoczów & $\begin{array}{l}290 \text { zł } \\
+20 €\end{array}$ \\
\hline & 3 & Lwów i Żółkiew & Lwów i Żółkiew & 565 zł \\
\hline \multirow{2}{*}{$\begin{array}{l}\text { PTT "Chortycia" } \\
\text { Przemyśl }\end{array}$} & 1 & $\begin{array}{l}\text { Wycieczka } \\
\text { do delfinarium }\end{array}$ & Truskawiec & $150 \mathrm{zł}$ \\
\hline & $1-2$ & Lwów z Przemyśla & Lwów & $\begin{array}{l}120 \text { zł } \\
\text { i } 320 \text { zł }\end{array}$ \\
\hline
\end{tabular}




\begin{tabular}{|c|c|c|c|c|}
\hline $\begin{array}{l}\text { Biuro podróży } \\
\text { Travel agency }\end{array}$ & $\begin{array}{l}\text { Czas } \\
\text { trwania } \\
\text { (dni) } \\
\text { Duration } \\
\text { (days) }\end{array}$ & $\begin{array}{l}\text { Nazwa wycieczki } \\
\text { Title of the tour }\end{array}$ & $\begin{array}{l}\text { Główne zabytki } \\
\text { Main sights }\end{array}$ & $\begin{array}{l}\text { Cena } \\
\text { Price }\end{array}$ \\
\hline \multirow{4}{*}{$\begin{array}{l}\text { PTT "Chortycia" } \\
\text { Przemyśl }\end{array}$} & 3 & $\begin{array}{l}\text { Lwów, Krzemieniec, } \\
\text { Zbaraż i zamki Złotej } \\
\text { Podkowy }\end{array}$ & $\begin{array}{l}\text { Lwów, Tarnopol, Zbaraż, Wiśniowiec, Poczajów, } \\
\text { Krzemieniec, Podhorce, Olesko, Złoczów, Lwów }\end{array}$ & $590 \mathrm{zł}$ \\
\hline & 4 & $\begin{array}{l}\text { Lwów, Żółkiew i zamki } \\
\text { Podkowy }\end{array}$ & Lwów, Olesko, Podhorce, Złoczów, Żółkiew & $690 \mathrm{zt}$ \\
\hline & 5 & Wycieczka na Podole & $\begin{array}{l}\text { Lwow, Olesko, Poczajów, Krzemieniec, Zbaraż, } \\
\text { Skała Podolska, Kamieniec Podolski, Chocim, } \\
\text { Okopy Św. Trójcy, Buczacz, Stanisławów, Lwów }\end{array}$ & $880 \mathrm{zt}$ \\
\hline & 6 & $\begin{array}{l}\text { Od Krzemieńca } \\
\text { do Kamieńca }\end{array}$ & $\begin{array}{l}\text { Łuck, Krzemieniec, Wiśniowiec, Zbaraż, Tarnopol, } \\
\text { Chocim, Kamieniec Podolski, Podhorce, Lwów, } \\
\text { Żółkiew }\end{array}$ & $1190 \mathrm{zt}$ \\
\hline \multirow{3}{*}{$\begin{array}{l}\text { Wycieczki na } \\
\text { Kresy } \\
\text { Pttk „Mazowsze” }\end{array}$} & 3 & Lwów & Lwów, Żółkiew & 515 zł \\
\hline & 3 & Lwów, Złota Podkowa & Lwów, Olesko, Podhorce, Złoczów & $569 \mathrm{zt}$ \\
\hline & 7 & $\begin{array}{l}\text { Jaskinie i zamki na } \\
\text { Podolu }\end{array}$ & $\begin{array}{l}\text { Tarnopol, jaskinia Młynki, jaskinia Kryształowa, } \\
\text { Kamieniec Podolski, Skała Podolska, Czerniowce, } \\
\text { Zaleszczyki, Jałowiec, Buczacz, Stanisławów, } \\
\text { Podhajce, Halicz, Rohatyń, Lwów, Żółkiew, } \\
\text { Krechów }\end{array}$ & $1310 \mathrm{zt}$ \\
\hline \multirow{9}{*}{ Quand (Zamość) } & $\begin{array}{l}1 \text { lub } 2 \\
1 \text { or } 2\end{array}$ & $\begin{array}{l}\text { Lwów - perła Galicji } \\
\text { Ni ma jak Lwów }\end{array}$ & Lwów & $\begin{array}{l}130 \text { lub } \\
349 \text { zł }\end{array}$ \\
\hline & 2 & Na szlakach Wołynia & $\begin{array}{l}\text { Włodzimierz Wołyński, Pawłówka, Beresteczko, } \\
\text { Łuck, Ołyka, Klewań, Równe, Dubno, Brody }\end{array}$ & 349 zł \\
\hline & 3 & Tylko we Lwowie & Lwów & $569 \mathrm{zt}$ \\
\hline & 4 & $\begin{array}{l}\text { Krzemieniec- } \\
\text { Kamieniec Podolski }\end{array}$ & $\begin{array}{l}\text { Brzeżany, Buczacz, Czortków, Kamieniec Podolski, } \\
\text { Okopy Swiętej Trójcy, Bakota, Skała Podolska, } \\
\text { Zbaraż, Wiśniowiec, Krzemieniec, Poczajów, } \\
\text { Podkamień, Olesko, Źółkiew }\end{array}$ & 669 zł \\
\hline & 4 & $\begin{array}{l}\text { Gdzie szum Prutu, } \\
\text { Czeremoszu }\end{array}$ & $\begin{array}{l}\text { Stanisławów, Jaremcze, Kołomyja, Kosów, Żabie, } \\
\text { Worohta, Bukowel, Truskawiec, Drohobycz }\end{array}$ & 649 zł \\
\hline & 5 & $\begin{array}{l}\text { Śladami Bohaterów } \\
\text { Trylogii }\end{array}$ & $\begin{array}{l}\text { Lwów, Złoczów, Zbaraż, Tarnopol, Mikulińce, } \\
\text { Trembowla, Czortków, Skała Podolska, Kamieniec } \\
\text { Podolski, Okopy Św. Trójcy, Chocim, Czerniowce, } \\
\text { Kołomyja, Iwano-Frankiwsk, Halicz, Żółkiew }\end{array}$ & 790 zł \\
\hline & 6 & $\begin{array}{l}\text { Szlakiem Kresowych } \\
\text { Strażnic }\end{array}$ & $\begin{array}{l}\text { Lwów, Olesko, Podhorce, Poczajów, Krzemieniec, } \\
\text { Wiśniowiec, Zbaraż, Skałat, Kamieniec Podol- } \\
\text { ski, Okopy Św. Trójcy, Bakota, Skała Podolska, } \\
\text { Jazłowiec, Buczacz, Mikulińce, Tarnopol, Brzeżany, } \\
\text { Lwów }\end{array}$ & 999 zł \\
\hline & 6 & Karpaty Wschodnie & $\begin{array}{l}\text { Iwano-Frankiwsk, Polanica, Kołomyja, Kosów, } \\
\text { Werhowyna (Żabie), Jaremcze, Worochta, Bukovel, } \\
\text { Bubniszcza }\end{array}$ & $995 \mathrm{zt}$ \\
\hline & 6 & $\begin{array}{l}\text { Szlakiem bohaterów } \\
\text { Trylogii Sienkiewicza }\end{array}$ & $\begin{array}{l}\text { Krechów, Żółkiew, Lwów, Olesko, Podhorce, } \\
\text { Złoczów, Zbaraż, Tarnopol, Skała Podolska, } \\
\text { Kamieniec Podolski, Chocim, Okopy Św. Trójcy, } \\
\text { Krzywcze, Jazłowiec, Buczacz, Stanisławów, } \\
\text { Drohobycz. }\end{array}$ & $860 \mathrm{zł}$ \\
\hline
\end{tabular}




\begin{tabular}{|c|c|c|c|c|}
\hline $\begin{array}{l}\text { Biuro podróży } \\
\text { Travel agency }\end{array}$ & $\begin{array}{l}\text { Czas } \\
\text { trwania } \\
\text { (dni) } \\
\text { Duration } \\
\text { (days) }\end{array}$ & $\begin{array}{l}\text { Nazwa wycieczki } \\
\text { Title of the tour }\end{array}$ & $\begin{array}{l}\text { Główne zabytki } \\
\text { Main sights }\end{array}$ & $\begin{array}{l}\text { Cena } \\
\text { Price }\end{array}$ \\
\hline \multirow[t]{2}{*}{ Quand (Zamość) } & 8 & $\begin{array}{l}\text { Szlakiem Kresowych } \\
\text { strażnic }\end{array}$ & $\begin{array}{l}\text { Chocim, Drohobycz, Kamieniec Podolski, Skała } \\
\text { Podolska, Tarnopol , Wiśniowiec, Zółkiew, } \\
\text { Krechów, Stanisławów, Buczacz, Czortków, Okopy } \\
\text { św. Trójcy, Żwaniec, Zbaraż, Krzemieniec, } \\
\text { Poczajów, Podhorce, Olesko, Lwów }\end{array}$ & 1280 zł \\
\hline & $8-20$ & Truskawiec & Truskawiec - miasto zdrowia & $\begin{array}{c}690- \\
1790 \text { zł }\end{array}$ \\
\hline \multirow{5}{*}{$\begin{array}{l}\text { Top Turystyka, } \\
\text { Katowice }\end{array}$} & 5 & $\begin{array}{l}\text { Lwów i zamki króla } \\
\text { Jana }\end{array}$ & $\begin{array}{l}\text { Krechów, Żółkiew, Lwów, Olesko, Podhorce, } \\
\text { Złoczów }\end{array}$ & $590 \mathrm{zł}$ \\
\hline & 4 & $\begin{array}{l}\text { Lwów - miasto } \\
\text { wspomnień }\end{array}$ & Lwów, Żółkiew, Krechów & 470 zł \\
\hline & 6 & Kresowa przygoda & $\begin{array}{l}\text { Żółkiew, Lwów, Olesko, Podhorce, Sasów, Złoczów, } \\
\text { Stare Sioło, Świrz, Stanisławów, Kołomyja, } \\
\text { Jaremcze, Czarnohora z Howerlą, przeł. Jabłonicka, } \\
\text { Bukowel, Worochta, Skały Dowbosza, Pniów, } \\
\text { Drohobycz, Sambor }\end{array}$ & $760 \mathrm{zł}$ \\
\hline & 7 & Szlakami Wołynia & $\begin{array}{l}\text { Krechów, Żółkiew, Sokal, Krystynopol, Tartaków, } \\
\text { Łuck, Beresteczko, Ołyka, Klewań, Równe, Ostróg, } \\
\text { Międzyrzecz, Nowomalin, Sławuta, Zasław, } \\
\text { Starokonstantynów, Poczajów, Krzemieniec, } \\
\text { Podkamień, Podhorce, Olesko, Lwów }\end{array}$ & 1180 zł \\
\hline & 7 & Kresowe strażnice & $\begin{array}{l}\text { Żółkiew, Lwów, Olesko, Podhorce, Brody, } \\
\text { Poczajów, Krzemieniec, Wiśniowiec, Zbaraż, } \\
\text { Tarnopol, Skałat, Satanów, Husiatyń, Sidorów, } \\
\text { Skała Podolska, Kamieniec Podolski, Chocim, } \\
\text { Żwaniec, Okopy św.Trójcy, Krzywcze, Czortków, } \\
\text { Buczacz, Stanisławów, Drohobycz }\end{array}$ & 1180 zł \\
\hline \multirow{3}{*}{ BP Wilejka } & 4 & Wycieczka do Lwowa & Lwów, Żółkiew, Olesko, Podhorce & $545 \mathrm{zł}$ \\
\hline & 6 & $\begin{array}{l}\text { Szlakiem bohaterów } \\
\text { trylogii }\end{array}$ & $\begin{array}{l}\text { Lwów, Zbaraż, Trembowla, Skała Podolska, } \\
\text { Kamieniec Podolski, Chocim, Jazłowiec, Buczacz, } \\
\text { Brzeżany, Lwów }\end{array}$ & 1090 zł \\
\hline & 8 & $\begin{array}{l}\text { Huculszczyzna (Ukra- } \\
\text { ina i Słowacja) }\end{array}$ & $\begin{array}{l}\text { Przemyśl, Drohobycz, Stanisławów, Kołomyja, } \\
\text { Tatarów, Nadwórna, Jaremcze, Worochta, Muka- } \\
\text { czewo, Użhorod, Preszów, Bardejów }\end{array}$ & $1500 \mathrm{zł}$ \\
\hline
\end{tabular}

Źródto: opracowanie własne na podstawie: http://www.bezkresy.pl/; http://www.wilejka.pl/; http://www. wycieczkinakresy.pl/; http://www.quand.com.pl/; http://www.kresy.com/; http://www.top.turystyka. pl/;http://bieszczader.pl/ (dostęp: 31.03.2019).

Source: author's own elaboration based on... http://www.bezkresy.pl/; http://www.wilejka.pl/; http:// www.wycieczkinakresy.pl/; http://www.quand.com.pl/; http://www.kresy.com/; http://www.top.turystyka. pl/http://bieszczader.pl/ (access: 31.03.2019). 